\title{
Hidden Slave Narratives: The Power of Teaching Empathy with Children's Literature
}

\author{
- Elisabeth Wilkes, Ball State University
}

A $\mathrm{s}$ incredible as it may seem, there was a time when we as children were blissfully unaware that slavery existed. Whether it was through parents, school, or something we saw on television, we learned that humans exploit and abuse others for their own personal and financial gain. Even more upsetting, we eventually learned that this is not an institution of the past. This evil still exists, despite it being so obviously horrendous and wrong. Some of us might have felt this injustice and wondered what we could do to stop the abom-

\section{Abstract:}

This essay investigates depictions of slavery in Holes (1997) and A Series of Unfortunate Events (1999) to argue that children's literature can be used to effectively teach empathy and to promote anti-slavery advocacy in children.

\section{KEY WORDS:}

Children Chapter Books, Historical Empathy, Teaching Empathy, Lemony Snicket, Louis Sachar, Contemporary Slavery, Holes, A Series of Unfortunate Events, The Miserable Mill, A Bad Beginning, Youth Advocacy ination. However, with no ready solution and few actual encounters with the institution itself, most accept it as a sad but inevitable evil.

If parents, educators, and advocates could prevent this apathy from developing, however, would the problem continue to exist? According to Nicolas M. Dahan and Milton Gittens, change can be enacted if advocates are able to frame their case and move the issue from private to public. There are three framings needed to shape a problem into a public ethical issue. First, the activist must use diagnostic framing, which is pointing out the problem, its causes, and its consequences. Then, the advocate must come up with a prognostic framing that gives a suggested solution or plan of attack to eliminating the problem. Finally, they must use motivational framing, which gives their cause urgency and a rationale as to why their issue must be addressed quickly (230). One popular and effective way to introduce this to the general public is to enlist the help of the media, which "challenge[s] public indifference to... slavery" and "creat[es] the incentives for responsive governments to take remedial action" (Van de Glind and Kooijmans 162). One popular form of media that is already doing this is the sharing of narratives of slaves, both fictional and actual, through literature. These narratives work to make the readers feel and experience the plight of their fellow man in a way that facts and statistics do not because they call the readers to empathize with the victims.

Countless children's books also address the issue of slavery and give their readers a historical context that is invaluable for their comprehension of the issue. As the mind grows and taste becomes more sophisticated, children should be challenged to grow in their understanding of books 
that are not explicitly about slavery but that include slave-like situations, especially since most of the slavery these readers will encounter in their lifetime will be underground and hard to spot. For this reason, I will examine the work Louis Sachar is doing with the issue in his book Holes and two of the thirteen books in Lemony Snicket's The Series of Unfortunate Events: The Bad Beginning and The Miserable Mill.

\section{Teaching Empathy Through Fiction}

Slavery is a difficult subject to teach for many reasons, the main one being the problem of depicting slavery correctly as well as helpfully. For history teachers especially, this issue presents a challenge because they not only need to teach the facts and the context, but also the skill of historical empathy. Jeffery Nokes defined historical empathy as "the ability to comprehend a historical individual's actions as a logical effect of his/her worldview" and claims this skill to be "among the most difficult of dispositions to develop, because they require unnatural thinking" (124). Historical empathy is unnatural because most concept-building practices take the inward to outward route, where the pupils draw from their own experiences and relate them to what they are trying to learn. Historical empathy takes the opposite approach, requiring students to go beyond their own surroundings and understand experiences that they are far removed from, and then relate those experiences to their own personal experience for comprehension. Many teachers attempt to remedy this dilemma in their history classes by incorporating historical fiction into their curricula. Fiction, more so than textbooks, engulfs the readers into the context and, if done masterfully, encourages the reader to understand perspectives through experiencing what the protagonist is sensing, encountering, and feeling.

With proper background information and careful reading selection, fiction has proved to be an effective tool in helping children grow in this empathy to understand past acts of slavery. They might not be able to comprehend all the complexities of the system, but they can start to build a clearer sense of how slavery affects people and why it was historically allowed to exist (Field 115). If fiction can be used to educate children about past slavery, then the same genre can help children encounter it in its current form. This can be done by developing a community perspective which teaches children that, as Sherry Field puts it, "they are not an island" (119). This me-centric logic is the default setting for childrens' minds due to the underdevelopment of empathy at that age. In her article "Transforming Status-Quo Stories: Shifting from 'Me' to 'We' Consciousness," AnaLouise Keating warns educators and parents against current education practices that perpetuate this dangerous thinking. In American school systems especially, where individualism is highly praised, extreme forms of egoism are teaching children to place the self above others, which "presumes and reinforces a model of domination, scarcity and separation in which intense competition leads to aggressiveness and fear: $m y$ growth requires your diminishment" (Keating 212). This idea is incredibly detrimental in a public that often allows slavery to exist because it benefits the public economically.

Keating calls for stories that encourage students to challenge the current status quo and recognize that their reality is interdependent on the existence of others. Without this outward awareness, children cannot understand their "accountability to others," and they can never "recognize that their actions have a profound effect on others" (Keating 215). These are the stories that awaken a sense of injustice needed for children to grow into ethically aware adults who desire 
to change the world's wrongs. Therefore, narratives need to teach not only how to empathize in general, but also how this empathy can become a call for action.

\section{Is Fiction the ANSWER?}

While teaching children about slavery at a young age would be the ideal for creating future advocates, educators are concerned with how much can be revealed about the institution. Teaching empathy is one thing, but to expose children to the full and accurate reality of slavery in order to create true empathy would require depicting families being ripped apart, traumatizing accounts of deception and abductions, and sexually explicit rape scenes. All these subjects are more than the average child can handle and are, therefore, omitted in children's literature. The economic, historical, and psychological complexities of slavery needed to fully understand the motivation of both slaveholders and the victims themselves also go well beyond the comprehension levels of children. For all these reasons, any children's book that does choose to depict slavery must simplify the issue and tone down or ignore some of the more disturbing aspects of the abuse.

Depicting slavery appropriately is already difficult without having to censor the narrative for children's eyes, but many authors have tried. John Bickford III and Cynthia Rich studied many of these attempts through historical fiction and uncovered some of the strengths and weaknesses of the pieces. While many of these depictions help children comprehend slavery, there are misrepresentations of slavery in the writing that educators need to consider before using the books in their curriculum. These misrepresentations occur in the minds of children as they process the story they are reading, giving them an incomplete understanding of slavery, past or present. For example, a logical fallacy labeled presentism occurs when children cannot move past their own viewpoints and try to project their retrospective knowledge onto the characters of a story (Bickford III and Rich 68). This becomes problematic in slave narratives, fictional or nonfictional, because children cannot understand how the victims get into the situation or why they cannot leave. The article cites the example of Primo Levi, who is often asked by children reading his true account in the labor camps during the Holocaust why he did not escape. This audience reads his story "not as one of survival but instead as a missed opportunity to escape and seek revenge on the guards" because, in their minds, that is what they believe they would do in the same situation (Bickford III and Rich 73).

Much of this type of thinking cannot be helped because of a child's limited intellectual maturity. However, authors can find ways around these limitations or can even find ways to teach children to struggle against these logical fallacies. While the article discussed above focuses on teaching children to understand past acts of slavery, any genre of fiction can do the same work to help children grasp and become aware of modern slavery. Educators and parents are raising the future generation who has the potential to change the lives of millions by eradicating slavery from every corner of the globe. If these children are led to believe that slavery was just a pre-Civil War problem, which unfortunately happens too often with the current model of education, they will not even know that there is a problem to be solved. They might encounter people who are victims of slavery but never label them as such because they have an out-of-date notion of what slavery looks like. Historical fiction is limited because it will always have that historical tinge to the reader. Other forms of children's fiction can go beyond facts and context and present students with the structure and attributes of slavery that transcend specific time periods of slavery to show what is universal 
throughout all the different types of slavery. To make these depictions as effective as possible, however, children need to be exposed to literature that does not fall into these logical traps. Louis Sachar's and Lemony Snicket's books are two examples that could be considered by educators to teach students the core structures of slave systems and explain the effects it has on its victims.

\section{Holes: Cover-ups ANd Slavery}

With the knowledge of what makes a piece of literature effective in teaching slavery, I will now look more closely at the first book, Holes, to analyze what a teacher or parent could use to help their children understand slavery. Louis Sachar's book captured the imaginations of children and won the National Book Award for Young People's Literature in 1998 and the Newbery Medal a year later. The story of an innocent but criminally-convicted teenager forced to dig a hole every day with other juvenile delinquents has the distinction of being both offbeat as well as severely dark. It encounters themes of fate, education, and self-improvement, while tackling issues such as persistent racial prejudices, legal corruption, and the exploitation of unprotected classes.

At first, it is not overtly obvious that the protagonist and his fellow campers have fallen victim to slavery. While Stanley may be wrongly imprisoned, the camp is meant to be a correctional facility. As the narrator explains, "[I]f you take a bad boy and make him dig a hole every day in the hot sun, it will turn him into a good boy" (Sachar 5). The camp counselors even attempt to teach the boys that they are not doomed cases and that they have the power to redeem themselves and assimilate back into society. While the boys quickly assume the prison-style life of picking nicknames for each other, Mr. Pendanski "prefer[s] to use the names their parents gave them- the names that society will recognize them by when they return to become useful and hardworking members of society" (Sachar 18). The boys are constantly reminded that their choices led them to digging these holes, so they have no right to complain. People on the outside believe in this model of correction and therefore have no reason to question the admittedly awful, but objectively fair, punishment.

On the surface, the camp's setup seems reasonable. The boys are provided for, though not handsomely, lest they enjoy it better than the broken lives that more often than not led them to the crimes they committed. Their punishment has an end date, meaning that the campers always know they will be able to leave. In short, the campers are treated just horribly enough to make them reluctant to commit a crime that would make them come back to the camp. However, Stanley soon recognizes that this is not an innocent operation. He finds a lipstick tube, which would eventually be revealed as a clue towards the treasure the camp counselor has set up the camp to find. After the owner of the camp, simply named the Warden, enters the scene and insists on making the hole where they find the tube an excavation site, he realizes " $t$ ] hey weren't just digging to 'build character.' They were definitely looking for something” (Sachar 71).

Once this thought is revealed to the reader, the camp begins to show its darker side. They start to move away from their original holes and begin a massive excavation project that progressively becomes more taxing than their previous labor. Stanley witnesses brutal abuses between the members of command, such as the Warden scratching Mr. Sir's face with rattlesnake venom-infused nail polish (Sachar 90). The boys fall victim to the Warden's growing agitation from the lack of progress, such as when she "jab[s] at Armpit with her pitchfork, knocking him backward into 
the big hole," which "le[aves] three holes in the front of his shirt, and three tiny spots of blood" (Sachar 78). Something unsettling is buried under the surface of this operation, and the more Stanley observes and digs, the more the cover-up begins to unravel.

The boys unknowingly begin to loose solidarity and turn on each other instead of against their masters. Interestingly enough, the only overt mention of slavery in the book occurs when the boys accuse Zero of being Stanley's slave after the two boys make the agreement that Stanley would teach Zero to read in exchange for Zero helping him finish his daily hole. Racial tensions begin to flair, enticing X-Ray to comment, "Same old story, ain't it ... The white boy sits around while the black boy does all the work" (Sachar 117). These jabs and remarks escalate over the following days, with Zigzag at one point suggesting that Stanley "should get a whip. Then if your slave doesn't dig fast enough, you can crack it across his back" (Sachar 132). Soon, the argument turns into physical fighting, with Mr. Pendanski egging them on. Finally, after Zero nearly strangles Zigzag to protect Stanley and hits Mr. Pendanski over the head with a shovel, Zero runs off into the desert to defy the oppressive system.

The most disturbing part of this book surrounds the character of Zero. His treatment by the staff of Camp Green Lake shows just how disposable these laborers become when their well-being interferes with the operation's goals. When he starts running, the only reason the Warden stops Mr. Sir from shooting him is because, "[ $\mathrm{t}$ ]he last thing we need is an investigation" (Sachar 139). When the trio is worried about what could happen if someone were to come and ask for him, Mr. Pendanski assures them that "[h]e had nobody ... He was nobody" (Sachar 144). Mr. Pendanski has always treated Zero differently from the other boys, even refusing to call him by his actual name, a courtesy he gives all the other campers. He feels that the name suits him because "there's nothing inside his head" (Sachar 19). In Mr. Pendanski's eyes, Zero is even lower in status than the other boys because he was a nuisance to society who no one would miss. His status as a homeless child makes him so easy to dismiss and also makes it simple to erase him from the records without fear of legal repercussions. In fact, if Stanley had not gone out to save Zero, no one outside of the system would even be aware that he was missing. Zero is a cautionary tale of what can happen when a person is wholly owned by the legal system and unscrupulous power holders use this fact to their advantage. Once they enter the penal system for any reason, they are powerless against exploitation.

Slavery has been tightly wound with the justice system in a twisted way for as long as law has been around. One major example in the last few centuries involved the Russian government. Starting in the reign of Peter the Great, criminals who committed capital offenses would be punished with a lifetime of hard labor, as well as loss of property and voidance of marriage (Patterson 43). They legally did not exist outside of the system, which gave the legal system the right to exploit them in any way the government saw fit. Incarceration necessarily involves convicts losing their rights as a consequence for breaking their social contract; but law enforcement can creep into abuses that toe, and sometimes cross, the line into slavery.

America has a particularly dark past with penal slavery due to the colonial transportation and exploitation of British convicts. According to Don Jordan and Michael Walsh, these slaves were "the first slaves in America and it was upon their labour, and later that of the African American slaves, that the nation was initially built" (19). During the seventeenth and eighteenth centuries, the problem of overcrowded prisons and a general wish to remove undesirables from the homeland induced Britain to create laws that sent these criminals to the colonies. This practice quickly became big business, with merchants claiming the convict trade to 
be "twice as profitable as the black slave trade" (Jordan and Walsh 248). Strangely enough, this system has two disturbing parallels to the fictitious Camp Green Lake. One is that children were the first to be sent away in the purge. In 1618, the authorities "swe[pt] up hundreds of troublesome urchins from the slums... and shipped them to Virginia" (Jordan and Walsh 12). The government claimed it to be an act of charity by giving the children the chance to live off the rich resources of the colonies that they could not find in the streets of London, but " $[\mathrm{i}]$ $\mathrm{n}$ fact, they were sold to planters to work in the fields and half of them were dead within the year" (Jordan and Walsh 13). These urchins sound similar to some members of the camp, most notably, Zero. The other eerie connection between the convict servant trade and the fictional camp's mission is that advocates for the perpetuation of the transportation claimed that the move and labor was for the "redemption of their souls" (Jordan and Walsh 258). This justification sounds dangerously close to the counselors' assurances that digging holes builds character. So, while Holes more directly alludes to the leftover tensions of African-American slavery, it has a closer correlation to this forgotten segment of colonial history.

Penal slavery in general is a difficult form of slavery because it complicates our view of victimhood. While it is easy to label the act as an injustice for the people who are innocent, such as Stanley in Holes, it seems more justified for guilty members of society. These victims seem to deserve their lot because they are paying back their debt to society for breaking the law. Citizens cannot see the crimes against dignity in labor camps, nor do they feel the need to investigate them to make sure these people are treated fairly. Without these investigations, however, more corrupt members of the system with agendas exploit a powerless labor force. These parties work within the system, even redefining laws to ensure that there is a steady flow of workers (Patterson 45). In the case of Holes, Camp Green Lake came into existence because the Warden saw an opportunity to get people to dig holes for her, creating a cover story that digging holes corrects criminal behavior. She connected this to the juvenile correction system so that she would never run out of young fit boys to do her work because "vacancies don't last long at Camp Green Lake” (Sachar 25).

This book tries to explain what happens when we allow our sense of justice to be twisted to the point that we lose sight of every person's right for human dignity. No one "deserves" slavery, and every victim needs champions to challenge corruption and expose their abuses to the public. In a system that often teaches children to trust people of authority, Holes encourages children to trust their instincts when they sense that something is off and investigate it to the best of their ability, just as Stanley does while in captivity. Stanley is not part of the group stereotypically exploited, but he learns to identify with this group through a shared experience. This experience is especially important for changing children's learned perceptions. For example, Mr. Pendanski, a seemingly kind and trustworthy adult, tells both Stanley and the readers what to believe about Zero. As the story progresses, and Stanley begins to see his fellow prisoners' worth, this view is complicated and eventually proven false. Once the protagonist's opinion begins to change, so does the reader's. Stanley's growth in empathy translates to the reader, not only giving him or her the ability to see this as exploitation and abuse, but also hopefully igniting a growing sense of injustice. This aversion to injustice drives Stanley to run after Zero, which could spur the readers to similar proactive decisions. If educators were able to harness this energy toward righting wrongs with their pupils, it could be a powerful tool for teaching the readers to grow up into advocates. 


\section{A Series of Unfortunate Events: The lot of the Powerless}

Our next author presents not only insights on how slavery can exist, but also helpful models for growing in empathy, which can be used to promote activism. Lemony Snicket published his first book in a thirteen book series two years after Sachar published Holes and took the children's literature market by storm. The first book, The Bad Beginning, won several awards, including the Colorado Children's Book Award, the Nevada Young Readers Award, and the Nene Award. Darker in subject than most other children's books on the shelves, the book begins with a house fire that leaves the protagonists, Violet, Klaus, and Sunny Baudelaire, as orphans and records the children's unfortunate lives through the span of thirteen books. Just when the reader thinks their lives cannot possibly become any more tragic, Snicket throws another tragedy into the mix. Snicket seems to break every rule about what to protect children from, only giving the readers a morsel of hope at the end to keep them going from book to book. It is no wonder that one of the issues he addresses is the cruelty adults can inflict on unprotected people for personal gain. This cruelty crosses the line into slavery more than twice, but I will focus on two prominent examples from the first and fourth installments in the series.

The Bad Beginning represents an unfortunately common glimpse into the life of domestic slavery. After the death of their parents, the Baudelaires are sent to live with a distant relative named Count Olaf. When first meeting him, the children already have an uneasy feeling about their new guardian, but Mr. Poe, who is in charge of their well-being, does not sense the danger and leaves them to start their new life. Olaf takes this opportunity as their new legal guardian to force the children into domestic servitude. Every morning, he leaves the children a list of instructions that includes "difficult chores, such as repainting the back porch or repairing the windows" (Snicket, Bad 30). Later, he requests that the children cook dinner for his entire acting troupe, even though the children have no idea how to cook. The children manage somehow, but they make pasta when Olaf is expecting roast beef. The scene takes an incredibly dark turn once their guardian finds out. Olaf turns to the orphans and says, "In agreeing to adopt you,' he said, 'I have become your father, and as your father I am not someone to be trifled with. I demand that you serve roast beef to myself and my guests'” (Snicket, Bad 46). Klaus stands up to Olaf saying that he is being unreasonable and cruel, to which the Count responds with a slap so hard to the boy's face that he falls to the ground. It becomes obvious to the children that this situation is well beyond just unreasonable parenting and is escalating into an abusive and slave-like situation.

When the children go to relate their plight to Mr. Poe, the readers get a disturbing glimpse at how the law can favor the privileged. Mr. Poe hears what the children have to say about the situation and responds, "Whatever Count Olaf has done ... he has acted in loco parentis, and there's nothing I can do about it. Your money will be well protected by myself and by the bank, but Count Olaf's parenting techniques are his own business" (Snicket, Bad 67). Essentially, he would do everything to protect their fortune, but because of loco parentis, which Snicket defines for the young readers as "in the place of parents," his hands are tied to protect them from their deplorable conditions. Jonathan Blagbrough explains that domestic slaves often experience an eerily similar situation because, "[a]s parental substitutes, employers may feel more at liberty physically to punish the child- especially as they interact in the private sphere ... the ambiguity of the relationship of the [Child Domestic Worker] to the employing family puts her in a legal vacuum as regards her careas she is considered neither a worker nor a family member" (185). Olaf's actions are protected by 
the law because the man in charge of the Baudelaires is too busy to ensure they are given a proper home and thinks that their fortune is worth protecting more than the children themselves.

Olaf uses the loopholes in the law again later on with his plans to marry Violet to legally obtain the inheritance. The plan is despicable, forcing the eldest under threat of her baby sister's life to go on stage and recite wedding vows in the guise of a play. Their neighbor, the kind but clueless Justice Strauss, is unknowingly brought into the plan, making the ceremony binding. What is disturbing, however, is how the adults react to Olaf's deception being revealed. The law states that this marriage is completely legal and, despite it being incredibly obvious that Violet was coerced into signing her name, Mr. Poe and Justice Strauss feel powerless to do anything because Olaf has followed the letter of the law. Only when Klaus reveals that the ceremony was voided because of a technicality do the adults think of trying to find a way to punish Olaf for his crimes.

To understand how these examples relate to modern slavery gives the readers a better understanding of how slavery is still allowed to exist, especially in areas where slavery is officially illegal. The Baudelaires almost fall victim to the legal mess that prevents current slave victims from escaping their captors. This is why antislavery advocates, such as Hans van de Glind and Joost Kooijmans, argue that "[c]lear, specific and unambiguous national laws against child slavery are crucial if it is to be addressed effectively" (160). The laws must be clear and well known because most victims do not have the same access to resources as the Baudelaires and cannot research how to work the system in their favor as Klaus does. In this tale, the law only protected the innocents because the innocents learned how to protect themselves. Most victims are not so fortunate because they are unaware of their rights in the first place. For example, Micheline Slattery, who started her journey into slavery in Haiti and was transported illegally to the United States, found herself in another slavery situation after she finally broke free. The man she was dating promised her citizenship and legal protection through marriage but then hung that protection over her to make her stay and be his sexual and domestic slave. She felt helpless to go to the police for fear of deportation. Eventually, she learned from a relative's lawyer that what her husband was doing was illegal and that, if she went to the authorities, she would still be allowed to stay in the country. What Slattery said about the ordeal was that, while legislatures had laws to protect people from legal repercussions, "few people know about these laws" (37). The Baudelaires have to read and study through obscure law books to find out how to escape Olaf's plan. Even so, because of the legal confusion, the adults of the book cannot act quickly enough to capture the Count. Had the protocol for their situation been less ambiguous, however, the legal system might have been able to stop Olaf then and there, saving the children from losing faith in their legal system and entering slavery for a second time.

The Miserable Mill shifts its focus from law to the power of business and money for inflicting the sorrows the orphans endure. Mr. Poe has dropped the kids off at Lucky Smells Lumbermill, frustrated by how quickly he is running out of convenient guardian options. In his haste, he hands their safekeeping to the owner of the mill, Sir, who takes advantage of the Baudelaires' need of protection against Olaf. Before he even meets the children, they find a memo on the door that reads: "Enclosed you will find a map of the Lucky Smells Lumbermill, including the dormitory where the three of you will be staying, free of charge. Please report to work the following morning along with the other employees" (Snicket, Miserable 17). They spend the night with other workers and report for dangerous amounts of labor with heavy machinery, where they are forced to work on a stick of gum for lunch and a communal casserole for dinner. After a morning of this labor, their employer/guardian calls them to meet him. Sir's business partner, 
Charles, greets them and is the only person truly alarmed to find out that they are working. $\mathrm{He}$ believes that there has been a huge misunderstanding and assures them that a meeting with his partner would clear up the confusion.

Once they meet Sir, however, the children find out that he is profiting on their desperation, finding more ways than paying his employees in coupons to avoid labor costs (Snicket 42). When Charles asks him to clear the apparent misunderstanding about the children's living arrangements, the businessman admits that there has been no mix up. He turns to the children and says, "The deal is this: I will try to make sure that Count Olaf and his associates never go anywhere near you, and you will work in my lumbermill until you come of age and get all that money. Is that a fair deal?" (Snicket, Miserable 52). The children are stunned at the proposition, as well as the narrator of the story who explains to his readers that, "A fair deal, as everyone knows, is when both people give something of more or less equal value.... working for years in a lumbermill in exchange for the owner trying to keep Count Olaf away is an enormously unfair deal" (Snicket, Miserable 53). This financial exploitation of the unprotected orphans also shows a dark side of business practices that are closer to this seemingly outrageous and fictitious account than we like to think.

The most disturbing part of this scene, however, is that Charles, who half owns the company, is convinced that Sir is asking something reasonable of these children. While he does not agree with his partner, he willingly witnesses this transaction and does nothing to aid the children. In many modern slave narratives, there are many men like Charles. These are the people who encounter the victim but, for one reason or another, do not act upon their suspicions. For example, Jill Leighton talks about how her captor was able to take her to hospitals with clear signs of abuse marking her body, but no one ever questioned his stories about how she obtained the injuries (77). There was even an instance when she saw "a lady getting into her Cadillac with her husband" who simply watched as her captor "was tying my hands behind my back and putting me back into the trunk in plain view" (Leighton 78). This practice of adults witnessing abuse but turning a blind eye is a common theme in Snicket's tales, revealing an unpleasant but all too common response to people in slave situations. Through the example of Charles, Snicket challenges his readers to see this tendency toward passivity and to fight against it to help those suffering.

No one comes to the aid of these orphans, which gives the readers the chance to witness the choices victims have to face when left to their own devices. The siblings feel so trapped that even when they have a chance to escape, Klaus stops them by pointing out, "But what if he found us... Who would protect us from Count Olaf, if we were all by ourselves?” (Snicket, Miserable 104). These orphans have no choice but to accept their slavery because Mr. Poe is too busy to protect them from not only homelessness, but also from an evil man who had already committed the murder of two of their previous guardians. Worse, Charles, who could have easily done something to prevent this cruel trade, stands by acting as if his partner is not taking advantage of the orphans' situation. This story portrays how feeling trapped and vulnerable can lead to people willingly giving up their rights for protection. The Baudelaires are especially susceptible to enslavement because " $[\mathrm{c}]$ hildren in slavery tend to be from disadvantaged populations.... The situation of such children is compounded by cultural values and practices that rank children low in status, which encourages others to disregard their rights" (Van de Glind and Kooijmans 162). Both Olaf and Sir exploited loopholes and vulnerabilities to ensure that the children ended up in these situations, which mirror the real world of modern slavery all too accurately. 
Snicket, more so than many children's authors, does not shy away from dark issues such as death, corruption, and violence. Even compared to Sachar, Snicket does not try to shield his readers from cruelty. From book one, page one, the narrator speaks of this tale as a story of misery and woe, warning people against reading it by stating:

If you are interested in stories with happy endings, you would be better off reading some other book. In this book there is no happy ending, there is no happy beginning and very few happy things in the middle....Violet, Klaus, and Sunny Baudelaire were ... extremely unlucky, and most everything that happened to them was rife with misfortune, misery, and despair. I'm sorry to tell you this, but that is how the story goes. (Snicket, Bad 1)

Our eyes naturally avert from suffering, but Snicket uses reverse psychology in a strange but effective way to combat that inclination. He is daring children to read it by telling them not to read it. Once he has them reading his tale, he is constantly trying to help his readers understand the Baudelaires' suffering by taking the narration out of the scene and addressing the audience directly. For example, after an emotional moment where Klaus shouts about his distress over his new living situation and the loss of his parents, his sister agrees softly, which creates a healing moment for the two. The reader might be confused how this made the two feel better because their situation is clearly not fixed. The narrator takes them aside to say, "Sometimes, just saying that you hate something, and having someone agree with you can make you feel better about a terrible situation" (Snicket, Bad 31).

Children's literature must teach empathy in this manner when trying to explain slavery because, if the children cannot understand a character's emotions or actions, the readers are lost. Victims of slavery often must do seemingly illogical things to survive for reasons that are beyond many people's comprehension. The job of any slave narrative, fictional or real, is to explain how they survived and to make the incredible sound reasonable. By properly explaining these extremes, audience members start to realize how desperate slavery makes the victim, and the experience awakens a sense of disgust towards the persecutors that creates a sense of urgency.

\section{Sachar and Snicket: Helpful Depictions?}

Both of these authors' works succeed in trying to build empathy and tackle the theme of power abuse that leads to exploitation of children. These depictions, whether intended or not, act as models of slavery that share attributes of both past and present slavery practices. But, are they helpful models that will give the reader a clearer sense of the causes and realities attached to this slavery? Or, do these depictions fall into logical traps that block students from understanding the issue of slavery better?

To answer this, we must return to some of the misrepresentations outlined in Bickford III and Rich's article that I discussed earlier. Both Sachar and Snicket have a lot to offer children, but they too are not perfect. For Holes, this trap is called heroification, which occurs in a narrative "when a lone person seemingly single-handedly transforms history" (Bickford III and Rich 69). Stanley definitely takes this role in the story because his actions and his insight not only save Zero and himself, but also shut the entire operation down. This gives readers the idea that individuals have a lot more agency than most victims of slavery actually have, which might give them the false impression that fighting slavery is only done by hero types who have everything going for them. This can be problematic because slavery can be abolished by ordi- 
nary, everyday people, but it requires working as a team and overcoming roadblocks. A Series of Unfortunate Events also has a misrepresentation. This is villianification, which occurs when an antagonist is "portrayed as only bad and without benefit of others' aid for misdeeds" (Bickford III and Rich 69). Snicket represents both Count Olaf and Sir as caricatures, presenting them as over-the-top evil. This actually makes it harder for the readers to identify those responsible for slavery because they assume that people who would be part of this exploitation would be easy to spot from a mile away.

A perfect depiction of slavery for children may not be possible, however, because the institution is multifaceted and complicated. Parents and educators must always be aware of a book's limitations and help the students understand what is fictional and what is real. However, just because a book cannot be perfect does not mean that it cannot do important work. Both books truly do call the readers to understand the plight of their heroes and lead them, either covertly, as with Sachar, or overtly, as with Snicket, toward an active understanding of how the protagonists are feeling. Readers are called to experience the pain slave systems inflict on their victims in a way that cannot be ignored. If educators can harness the power of this empathy, they can prevent children from falling into eventual apathy for the issue. This could inspire children to grow up and be champions for people who live the actual pain portrayed in these books. If this could happen with enough children, perhaps we would be one step closer to global abolition of slavery. 


\section{Works Cited}

Bickford III, John H and Cynthia W. Rich. "Examining the Representation of Slavery Within Children's Literature." Social Studies Research and Practice 9.1 (Spring 2014): 66-94. Print.

Blagbrough, Jonathan. “Child Domestic Labour: A Modern Form Of Slavery.” Children \& Society 22.3 (2008): 179-190. Web. 16 Jan. 2015.

Dahan, Nicolas M. and Milton Gittens. "Business and the Public Affairs of Slavery: A Discursive Approach of an Ethical Public Issue.” Journal of Business Ethics 92.2 (Mar., 2010): 227-249. Web. 16 Jan. 2015.

Field, Sherry L. "Perspectives and Elementary Social Studies: Practice and Promise." Historical Empathy and Perspective Taking in the Social Studies. Lanham: Rowman \& Littlefield, 2001: 115-138. Print.

Jordan, Don, and Michael Walsh. White Cargo: The Forgotten History of Britain's White Slaves in America. Washington Square, NY: New York UP, 2008. Print.

Keating, AnaLouise. “Transforming Status-Quo Stories: Shifting from 'Me' to 'We' Consciousness." Education and Hope In Troubled Times: Visions of Change for Our Children's World. New York: Routledge, 2009: 210-222. Print.

Leighton, Jill. "My Life as a Slave in America." Enslaved: True Stories of Modern Slavery. Eds. Jess Sage and Liora Kasten. New York: Palgrave Macmillan, 2006: 61-80. Print.

Nokes, Jeffery. “Developing Historical Empathy and Perspective Taking Through Historical Fiction.” Building Students' Historical Literacies. Hoboken: Taylor and Francis, 2013. 118-132. Print.

Patterson, Orlando. Slavery and Social Death: A Comparative Study. Cambridge, MA: Harvard UP, 1982. Print.

Sachar, Louis. Holes. New York : Farrar, Straus and Giroux, 1998. Print.

Slattery, Micheline. "The Journey of an Orphan: In and Out of Bondage from Haiti to Connecticut." Enslaved: True Stories of Modern Slavery. Ed. Jess Sage and Liora Kasten. New York: Palgrave Macmillan, 2006: 11-38. Print.

Snicket, Lemony. A Series of Unfortunate Events: The Bad Beginning. New York: HarperTrophy, 1999. Print.

---. A Series of Unfortunate Events: The Miserable Mill. New York: HarperTrophy, 2000. Print.

Van de Glind, Hans, and Joost Kooijmans. "Modern-Day Child Slavery." Children \& Society 22.3 (2008): 150-166. Web. 16 Jan. 2015. 